\title{
Occurrence of anthracnose, caused by Colletotrichum gloeosporioides, on Lycoris radiata in Korea
}

\author{
Jung Han Lee ${ }^{1}$ - Youn-Sig Kwak ${ }^{2}$ \\ Received: 18 January 2015 / Accepted: 1 April 2015 / Published online: 17 April 2015 \\ (C) Australasian Plant Pathology Society Inc. 2015
}

\begin{abstract}
Anthracnose symptoms were observed on leaves of red spider lilies in Korea. At the early stages of infection the symptoms appeared as small red spots on the leaves. In later stages, the infected leaves gradually turned yellow to brown and developed wilting symptoms. The pathogen isolated from the infected leaves of red spider lily was identified as C. gloeosporioides by morphological and molecular characteristics. C. gloeosporioides was confirmed as the pathogen responsible for the observed symptoms by performing a pathogenicity test.
\end{abstract}

Keywords Amaryllidaceae · Anthracnose · Colletotrichum gloeosporioides $\cdot$ Lycoris radiate $\cdot$ Red spider lily

The red spider lily (Lycoris radiata) belongs to the family Amaryllidaceae and is a fall-blooming perennial bulb native to China. The bulb of the red spider lily has been used as a medicinal plant in Asia and also as an emergency food item during ancient times ( $\mathrm{Ji}$ and Meerow 2000; Kurita 1998). This plant is also used to prevent soil erosion and suppress weed growth in paddy fields (Itoh and Takahashi 1997; Takahashi and Itoh 1997; Takahashi et al. 1998). Colletotrichum spp. is one of the most destructive fungal genera, causing anthracnose symptoms in host plants that range broadly in type and include different 44 varieties of fruits, crops, and ornamental plants (Baily et al. 1992).

Youn-Sig Kwak

kwak@gnu.ac.kr

Korea Turfgrass Research Institute, Seongnam 463-840, Korea

2 Department of Plant Medicine and Research Institute of Life Science, Gyeongsang National University, Jinju 660-701, Korea
This genus is capable of infecting its host at the blossom, stem, fruit, root, leaf, and other parts of the plant. However, anthracnose symptoms in the red spider lily have not yet been associated with $C$. gloeosporioides. In this study, we identified this pathogen in a direct causal association with the anthracnose symptoms in L. radiata.

In October 2013, anthracnose symptoms were observed in seedlings of red spider lily located in Southern Forest Resource Research Center, Jinju, South Korea. The symptoms were red circles varying from 0.5 to $2 \mathrm{~cm}$ in size with a brownish color at the spot center, where the tissue appeared to be dehydrated (Fig. 1a). As the disease progressed, the small red spots that first appeared on the leaves gradually grew larger in size, and the infected leaves later changed in color from yellow to brown. While Liu et al. (2000) have previously reported observations of anthracnose diseases in the family of Amaryllidaceae plants, to the best of our knowledge, no instances of anthracnose symptoms in L. radiata have been previously reported. We isolated the pathogen causing anthracnose symptoms in the red spider lily by removing it from the leaves by using the surface sterilization method (1\% bleach solution for $1 \mathrm{~min})$. The pathogen was grown on potato dextrose agar (PDA) for 5 days at $28{ }^{\circ} \mathrm{C}$. The optimum conditions for mycelia growth were determined to be a $\mathrm{pH}$ of 5.5 at $27^{\circ} \mathrm{C}$ on PDA (data not shown). The representative pathogen isolate was deposited in the Korean Agricultural Culture Collection Center (KACC\#47837).

Mycelia on the PDA medium appeared pale gray in the inner regions and white at edges. The isolates produced pink spores in a mucilaginous matrix (Fig. 1b). The morphological characteristics of conidia can be described as hyaline in appearance, aseptate and ellipsoid in structure (13.6-16.4 $\times 5.1-7.2 \mu \mathrm{m}$; Fig. 1c). These morphological characteristics were in close 


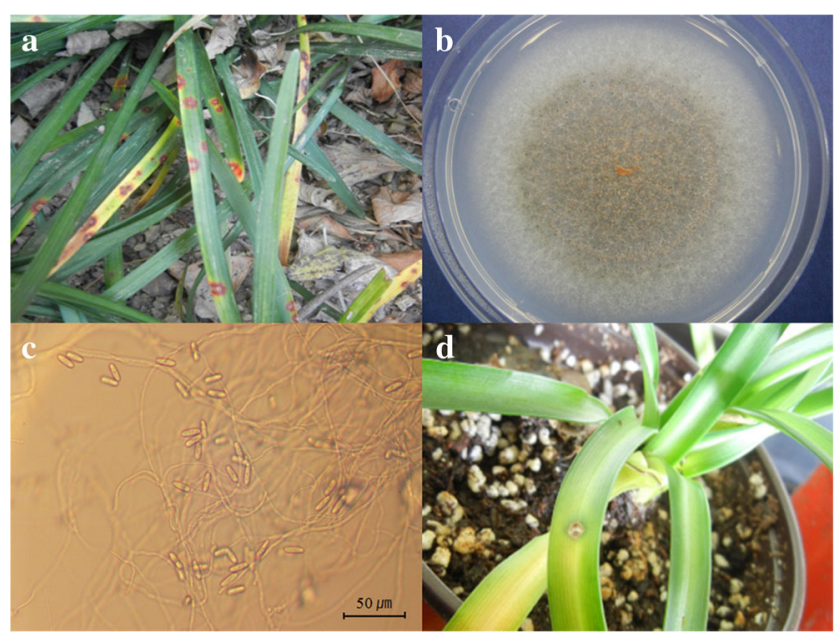

Fig. 1 Symptoms and morphological characteristics of Colletotrichum gloeosporioides in Lycoris radiate a: Typical symptoms of anthracnose on red spider lily leaves in field condition. b: Colony morphology of the pathogen on PDA media. c: Conidiospores of C. gloeosporioides. d: Anthracnose symptom was artificially induced, by the inoculation of Lycoris radiate leaves with isolated $C$. gloeosporioides

correspondence with morphological records for C. gloeosporioides described by Bailey et al. (1992). To test pathogenicity, the isolate was incubated for 1 week on PDA at $28{ }^{\circ} \mathrm{C}$ to induce sporulation. To separate the spores from the mycelium, the petri dish containing the pathogen was washed with $10 \mathrm{ml}$ of sterilized water and then sieved through a cheesecloth twice. The inoculum suspension was adjusted to a concentration of $1 \times 10^{6}$ spores $/ \mathrm{ml}, 10 \mu \mathrm{l}$ of which was inoculated onto healthy leaves that were wounded by a needle. The inoculated red spider lily was kept for 1 week in $90 \%$ relative humidity at $28{ }^{\circ} \mathrm{C}$. Mock inoculations (sterilized water) were also performed to serve as controls. Within 5 days of the artificial inoculation of the plant with the pathogen spore suspension, typical anthracnose symptoms appeared on the leaf surface: At 2 days after infection, small and brown spots were observed and after 5 days, the spots developed into large lesions (Fig. 1d). These symptoms were similar to those observed on the red spider lilies in the fields. The mock-inoculated plant did not develop any disease lesions and only exhibited signs of the needle wound. The pathogen was re-isolated from the disease lesions of inoculated leaves and analyzed for morphological characteristics. The characteristics of these re-isolated pathogens were indistinguishable from those in the original isolates.

Fungal mycelium was separated from the PDA medium by using an inoculating loop, and a sample was prepared for DNA extraction. Total genomic DNA of the fungus was extracted using a modified cetyltrimethylammonium bromide DNA extraction protocol (Graham et al. 2003). To identify
Fig. 2 Phylogenetic identification of C. gloeosporioides based on internal transcribed spacer (ITS) rRNA sequences. Numerical values on branches are bootstrap values calculated as a percentage of bootstrap replications from 1000 replicate analyses. C. gleosporioides Funbio5 represented the isolate (KJ563297.1). A phylogenetic tree inference was conducted with the MAGA 5 program and phylogenetic distances were calculated using the neighborjoining method. Bar $=0.05$ units of genetic distance between samples. Rhizoctonia solani and Alternaria tenuissima served as out-group references (Weir et al. 2012)

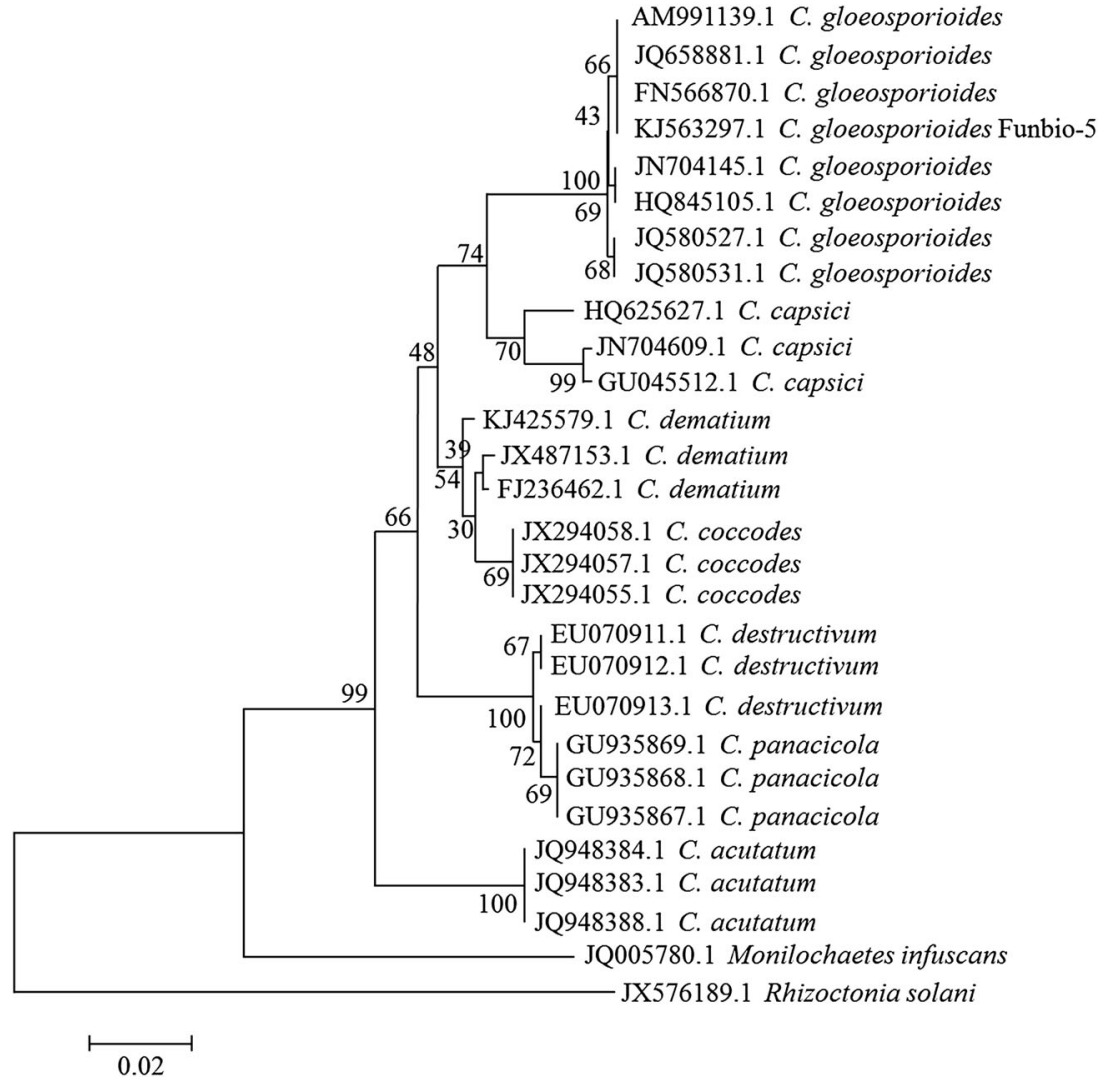


the fungus, a region within the internal transcribed space (ITS) of the rRNA was amplified using the primers ITS1 (5'-TCCGTAGGTGAACCTGCGG-3') and ITS4 (5'-TCCT CCGCTTATTGATATGC-3') (White et al. 1990). The ITS region amplification was carried out in $20 \mu \mathrm{l}$ of reaction mixture containing $50 \mathrm{ng}$ of the template DNA, 10 pico moles of each of the ITS1 and ITS4 primers, $1 \mu$ of Taq DNA polymerase, $1 \mu \mathrm{l}$ of dNTP, $2 \mu \mathrm{l}$ of $10 \times$ reaction buffer and topped to $20 \mu \mathrm{l}$ with deionized distilled water. PCR conditions were as follows: pre-denaturation at $94{ }^{\circ} \mathrm{C}$ for $5 \mathrm{~min} ; 30$ cycles of denaturation at $94{ }^{\circ} \mathrm{C}$ for $30 \mathrm{~s}$ in each cycle, annealing at $55{ }^{\circ} \mathrm{C}$ for $45 \mathrm{~s}$, and extension at $72{ }^{\circ} \mathrm{C}$ for $40 \mathrm{~s}$; and a final extension at $72{ }^{\circ} \mathrm{C}$ for $10 \mathrm{~min}$. The sequence was deposited in GenBank (NCBI accession No. KJ563297.1) and compared with sequences in the GenBank database using BLAST. BLAST results for the ITS showed $100 \%$ similarity to sequences belonging to $C$. gloeosporioides strains (such as its teleomorph: Glomerella cingulate (Stoneman) Spauld. \& H. Schrenk). These results confirm our previous conclusions based on morphological similarities, that the fungus responsible for anthracnose in the L. radiata was $C$. gloeosporioides (Fig. 2).

Acknowledgments This research was performed with the support of the "Export strategy \& technology development (114095-3)" from IPET, Korea.

\section{References}

Bailey JA, O'Connell RJ, Pring RJ, Nash C (1992) Infection strategies of Colletotrichum species. In: Bailey JA, Jeger MJ (eds) Colletotrichum: biology, pathology and control. CAB International, Wallingford, pp 88-120

Graham J, Marshall B, Squire G (2003) Genetic differentiation over a spatial environmental gradient in wild Rubus idaeus populations. New Phytol 157:667-675

Itoh M, Takahashi M (1997) The allocation pattern of the allelochemical of Lycoris radiata into its scaly leaf and flowering scape. J Weed Sci Technol 42:116-117

Ji ZH, Meerow AW (2000) Amaryllidaceae. In: Flora of China, 24. Beijing, Science Press, and St. Louis, Missouri Botanical Garden Press

Kurita S (1998) Natural History of Higanbana (Lycoris radiata). Tokyo Kensei-shya Press, Tokyo, pp 177-188

Liu SQ, Zhao DQ, Liang GP, Zhou HL, Zhao LF (2000) List of ornamental disease in Xishuangbanna. Fujian Sci Technol Trop Crop 25:42-48

Takahashi M, Itoh M (1997) The role of scaly leaf of Lycoris radiata on its allelopathy. J Weed Sci Technol 42:118-119

Takahashi M, Itoh M, Nakai K (1998) Action of allelopathy by change with growth of Lycoris radiata bulbs in early summer. J Weed Sci Technol 43:186-187

Weir BS, Johnston PR, Damm U (2012) The Colletotrichum gloeosporioides species complex. Stud Mycol 73:115-180

White TJ, Bruns T, Lee S, Taylor JW (1990) Amplification and direct sequencing of fungal ribosomal RNA genes for phylogenetics. In: Innis MA, Gelfand DH, Sninsky JJ, White TJ (eds) PCR protocols: a guide to methods and applications. NY, USA, Academic Press, New York, pp 315-322 